\title{
Simple, Rapid and Selective Chronopotentiometric Method for the Determination of Riboflavin in Pharmaceutical Preparations Using a Glassy Carbon Electrode
}

\author{
Tanja Brezo, ${ }^{1}$ Zorica Stojanović, ${ }^{1, *}$ Zvonimir Suturović, ${ }^{1}$ Snežana Kravić, ${ }^{1}$ \\ Jovana Kos ${ }^{2}$ and Ana Đurović ${ }^{1}$ \\ ${ }^{1}$ University of Novi Sad, Faculty of Technology, Department of Applied and Engineering Chemistry, Bulevar cara Lazara 1, \\ 21000 Novi Sad, Serbia \\ ${ }^{2}$ University of Novi Sad, Institute of Food Technology, Bulevar cara Lazara 1, 21000 Novi Sad, Serbia \\ *Corresponding author: E-mail: zokastojanovic@ gmail.com
}

Received: 09-06-2015

\begin{abstract}
A novel, simple, sensitive and reliable electrochemical method for the riboflavin determination using chronopotentiometry with glassy carbon electrode was developed. The most important instrumental parameters of chronopotentiometry including type and concentration of supporting electrolyte, initial potential and current range were examined and optimised in respect to riboflavin analytical signal. Riboflavin provided well defined reduction signal at $-0.12 \mathrm{~V} v s$. $\mathrm{Ag} / \mathrm{AgCl}(3.5 \mathrm{~mol} / \mathrm{L} \mathrm{KCl})$ electrode in $0.025 \mathrm{~mol} / \mathrm{L} \mathrm{HCl}$. Under optimal conditions, linear response of riboflavin was observed in the concentration range of $0.2-70 \mathrm{mg} / \mathrm{L}$ with achieved limit of detection of $0.076 \mathrm{mg} / \mathrm{L}$ and limit of quantitation of $0.23 \mathrm{mg} / \mathrm{L}$ of riboflavin. Common vitamins and excipients did not interfere with the determination. The proposed method was successfully applied for determination of riboflavin in commercially available pharmaceutical preparations. The obtained results were in statistical agreement to the contents declared by manufacturer and to those obtained by HPLC used as a comparative method.
\end{abstract}

Keywords: Riboflavin, chronopotentiometry, glassy carbon electrode, pharmaceutical preparations

\section{Introduction}

Riboflavin (7,8-dimethyl-10-[(2S,3S,4R)-2,3,4,5tetrahydroxypentyl]benzo[ $g$ ]pteridine-2,4-dione), commonly named vitamin $B_{2}$, is a water soluble vitamin belonging to B-complex (Figure 1).

The compound exerts its biological function through two flavin coenzymes: flavin mononucleotide (FMN) and flavin adenin dinucleotide (FAD). The coenzymes participate in a range of redox reactions in intermediary metabo-<smiles>Cc1cc2nc3c(=O)[nH]c(=O)nc-3n(CCO)c2cc1C</smiles>

Figure 1. The structural formula of riboflavin. lism by accepting and donating two electrons in the isoalloxazine ring. ${ }^{1}$ These reactions are substantial for tissue respiration, normal cellular function, growth, and development. Although riboflavin is found distributed in virtually all naturally occurring foods, especially rich sources of this vitamin are milk and dairy products, meat, eggs, livers, cereals and fresh leafy vegetables. ${ }^{1-3}$ Regular daily intake of riboflavin is important because it is not stored in human body in appreciable amounts. Though no pathologically severe symptoms attributed to vitamin $\mathrm{B}_{2}$ deficiency have been observed in humans, diets lacking the vitamin caused lesions of the muco-cutaneous surfaces and intense photophobia. ${ }^{4}$ The low solubility of riboflavin and the limited capacity for intestinal absorption probably account for the lack of toxicity. ${ }^{4}$ Recommended daily intake of riboflavin for adult is $1.1 \mathrm{mg}$ for men and $1.3 \mathrm{mg}$ for women. ${ }^{5}$ Some conditions such as pregnancy and lactation require an increase to recommended intake. Further, stress and heavy exercise may increase riboflavin 
requirements as well..$^{5}$ Balanced diet provides sufficient amounts of riboflavin to healthy individuals. If those amounts are not ensured by food, pharmaceutical preparations containing this vitamin may be alternative. Also, supplements may be of benefit for those at risk of deficiency, particularly for elderly people, alcoholics and those with absorption difficulties. ${ }^{5}$ In recent times a large number of riboflavin containing pharmaceutical preparations and dietary supplements are present on the market. Riboflavin containing pharmaceutical products range in complexity from single vitamin to multivitamin and mineral formulations. Usually riboflavin is a part of a multinutrient formulation, particularly as a component of a Bcomplex. In order to ensure adequate quality control and for assessment of compliance with the recommendations for daily riboflavin intake, accurate and fast method for determination of riboflavin in pharmaceutical preparations is of crucial importance.

Many analytical methods for the determination of riboflavin have been reported. The standard method for riboflavin determination in food is the fluorimetric method, defined by Association of Official Analytical Chemists. ${ }^{6}$ The other used techniques are spectrophotometry, ${ }^{7-9}$ chemiluminescence, ${ }^{10}$ capillary electrophoresis, ${ }^{11-13}$ and the most frequently used HPLC. ${ }^{14-17}$ These methods have demonstrated good sensitivity and selectivity, but their implementation requires specialised expensive equipment and the procedures may be rather complicated and time-consuming. Contrary, electrochemical methods have been of great interest because they are rapid, reliable, more economic and suitable for in situ analysis. Electrochemical determination of riboflavin is possible due to its electro-reduction on the electrode surface. In general, it is believed that electro-reduction of riboflavin is a reversible process involving two electrons and two protons (Figure 2). ${ }^{18,19}$

Among electrochemical methods, those based on voltammetry and voltammetric stripping analysis are mostly used for riboflavin assays. ${ }^{1,18-22}$ Various types of electrodes were considered in analysis of riboflavin, including mercury electrodes, ${ }^{22,23}$ gold electrode, ${ }^{18}$ different types of carbon paste electrode, ${ }^{2,22,24}$ glassy carbon electrodes, ${ }^{25,26}$ and bismuth based electrodes. ${ }^{27,28}$ Most of the mentioned electrodes are complicated to prepare, often with low reproducibility of fabrication. In some cases, additional pre-treatment and activation step is necessary as well. Thus, the design and development of fast, simple, inexpensive and effective methods are of great importance in practice.

To date, no report has appeared in the literature describing the analytical utility of chronopotentiometry on glassy carbon electrode in the determination of riboflavin. Hence, the present study is dealing with a quantitative determination of riboflavin using direct chronopotentiometric method on a glassy carbon electrode. This electroanalytical technique is simple, rapid, reproducible and easy to apply in routine usage. In addition, easy preparation and no risk of mechanical damage of the glassy carbon electrode are very advantageous. Therefore, proposed chronopotentiometric method applicability to the determination of riboflavin in pharmaceutical preparations was evaluated in this study.

\section{Experimental}

\section{1. Chemicals and Reagents}

Riboflavin, thiamine and pyridoxine were obtained from Sigma-Aldrich (Germany) and used as received. Acetic acid, sodium acetate, sodium chloride and potassium chloride were obtained from Centrohem (Serbia). Citric acid and sodium citrate were supplied by Zorka Pharma (Serbia) while ascorbic acid was acquired from Kemika (Croatia). All other chemicals used were of analytical grade purity (Merck, Germany). Doubly distilled water was used throughout the experiments. Riboflavin stock solution $(1 \mathrm{~g} / \mathrm{L})$ was prepared daily by dissolution of solid standard in double-distilled water. The stock solution was stored in the refrigerator in a glass flask covered by aluminium foil. Working standard solutions of riboflavin were prepared by appropriate dilutions of the stock solution with supporting electrolyte. Acetic buffer was prepared by mixing of acetic acid and sodium acetate (all at $0.5 \mathrm{~mol} / \mathrm{L}$ concentration). Citrate buffer was prepared by mixing $0.1 \mathrm{~mol} / \mathrm{L}$ citric acid and $0.1 \mathrm{~mol} / \mathrm{L}$ sodium citrate in appropriate amounts. For $\mathrm{pH}$-adjustment $2 \mathrm{~mol} / \mathrm{L}$ potassium hydroxide was employed.

\section{2. Instrumentation}

An automatic analyser (M1 analyser) for potentiometric and chronopotentiometric stripping analysis of our own construction was used in this study. ${ }^{29}$ The qualitative and quantitative characteristics of the analyte were deter-

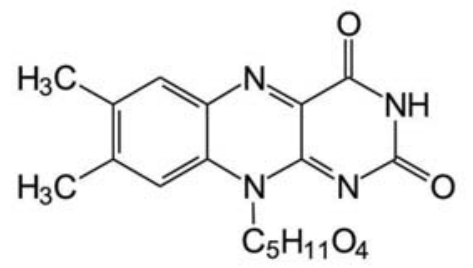<smiles>Cc1cc2c(cc1C)N([13CH3])c1[nH]c(=O)[nH]c(=O)c1N2</smiles>

Figure 2. The electro-reduction mechanism for riboflavin. ${ }^{18}$ 
mined automatically by M1 analyser. Qualitative characteristic of the analyte is the reduction potential while quantitative characteristic is the transition time. The transition time was measured as a time between two inflection points. Inflection points were determined by program derivatization and were indicated at the chronopotentiogram as horizontal dotted lines. The M1 analyser was connected to EPSON-570+ printer providing output records.

A glassy carbon planar disc electrode of $7.07 \mathrm{~mm}^{2}$ total surface area was used as working electrode. An $\mathrm{Ag} / \mathrm{AgCl}(3.5 \mathrm{~mol} / \mathrm{L} \mathrm{KCl})$ electrode was used as a reference and a platinum wire $(\varnothing 0.7 \mathrm{~mm}, 1=7 \mathrm{~mm})$ served as an auxiliary electrode. In order to renew the electrode surface, the glassy carbon electrode was polished with aqueous suspension of aluminium oxide (grain size $=0.5 \mu \mathrm{m}$ ) on a polishing micro-cloth. After polishing, electrode was rinsed with acetone and double-distilled water and sonicated in water-ethanol $(1: 1, v / v)$ mixture for $5 \mathrm{~min}$ to remove impurities. Prior to each analysis, the surface of glassy carbon disc electrode was cleaned with quantitative filterpaper, wetted firstly with acetone, and then with doubledistilled water. The polishing procedure was repeated weekly or when reproducibility of the electrode worsened. Prior to each analysis the planar disc electrode was electrochemically cleaned by a constant current of $7.2 \mu \mathrm{A}$ in 30 potential cycles from $-0.8 \mathrm{~V}$ to $0.8 \mathrm{~V}$ in $0.025 \mathrm{~mol} / \mathrm{L}$ $\mathrm{HCl}$.

The laboratory accessories used were cleaned firstly by immersion in a nitric acid - water mixture $(1: 1, v / v)$, and then rinsed with distilled and double-distilled water. All experiments were carried out at room temperature (23 $\left.\pm 2{ }^{\circ} \mathrm{C}\right)$.

\section{3. Samples and Sample Preparation}

All investigations were performed by using commercial riboflavin containing pharmaceutical preparations, including two types of multivitamin tablets (MVT1, MVT2), three different vitamin B complex tablets (BCT1, BCT2, BCT3) and three kinds of multivitamin granules (MVG1, MVG2, MVG3). The preparations were purchased from local drugstores (Novi Sad, Serbia).

In order to prepare sample for analysis, each tablet was powdered in a grinding mortar and dissolved in supporting electrolyte, sonicated for $15 \mathrm{~min}$, and then filtered through a Whatman no. 1 filter paper (Whatman International, Maidstone, UK). The filtrate plus washing solutions of the insoluble residue were diluted with supporting electrolyte to $50 \mathrm{~mL}$ in a volumetric flask covered with aluminium foil. Aliquot of $20 \mathrm{~mL}$ was taken to the electrochemical cell for chronopotentiometric analysis. In the case of granules, appropriate amount of granules was dissolved in supporting electrolyte to the concentration of approximately $5 \mathrm{mg} / \mathrm{L}$ and $10 \mathrm{mg} / \mathrm{L}$ of riboflavin. The resulting solution was filtered and filtrate then analysed directly by the proposed chronopotentiometric method.
For HPLC analysis, after powdering, tablet was dissolved in double distilled water and sonicated for $15 \mathrm{~min}$. The solution was then filtrated through Whatman no. 1 filter paper and membrane syringe filter with pore diameter of $0.45 \mu \mathrm{m}\left(\right.$ Chromafil $^{\circledR}$ Xtra PET-45/25, Macherey-Nagel, Düren, Germany). The filtrate plus washing solutions of the insoluble residue were diluted with double distilled water to $50 \mathrm{~mL}$ in a volumetric flask covered with aluminium foil. Sample prepared in this way was used for HPLC analysis of riboflavin.

\section{4. Optimisation and Validation Procedures}

In order to optimise electrochemical determination of riboflavin by using chronopotentiometry, the influence of the most important experimental parameters including the type and concentration of the supporting electrolyte, initial potential and reduction current were examined. For selection of optimal parameters for chronopotentiometric determination, height, sharpness and reproducibility of riboflavin electroanalytical signal were considered.

Performance characteristics of the optimised method were established by a validation procedure with spiked and real samples, studying linearity, limits of detection (LOD) and quantification (LOQ), precision, selectivity and accuracy. Estimation of proposed method accuracy was done by means of HPLC parallel analysis.

\section{5. HPLC Analysis}

HPLC analysis of the samples was carried out using "Agilent 1200" system (Agilent Technologies Inc., USA) equipped with diode array detector (DAD), Chemstation Software, binary pump, vacuum degasser, auto sampler and Agilent column (Eclipse XDB-C18, $1.8 \mu \mathrm{m}, 4.6 \times 50$ $\mathrm{mm})$. The DAD detector was set to $260 \mathrm{~nm}$. As a mobile phase, $0.1 \%$ formic acid - methanol $(85: 15, v / v)$ mixture was applied. All analyses were performed under isocratic conditions at a mobile phase flow rate of $0.6 \mathrm{~mL} / \mathrm{min}$ and column temperature of $30{ }^{\circ} \mathrm{C}$. Injection volume was $5 \mu \mathrm{L}$. All solvents were degassed in an ultrasonic bath and filtrated through a $0.45 \mu \mathrm{m}$ filter before use. Each sample was prepared and analysed in five replicates. Quantitative analysis in liquid chromatography was carried out by the calibration curve method.

\section{Results and Discussion}

\section{1. Chronopotentiometric Study of Riboflavin}

Figure 3a shows the background chronopotentiometric response of a glassy carbon electrode in pure supporting electrolyte $(0.025 \mathrm{~mol} / \mathrm{L} \mathrm{HCl})$, while chronopotentio- 


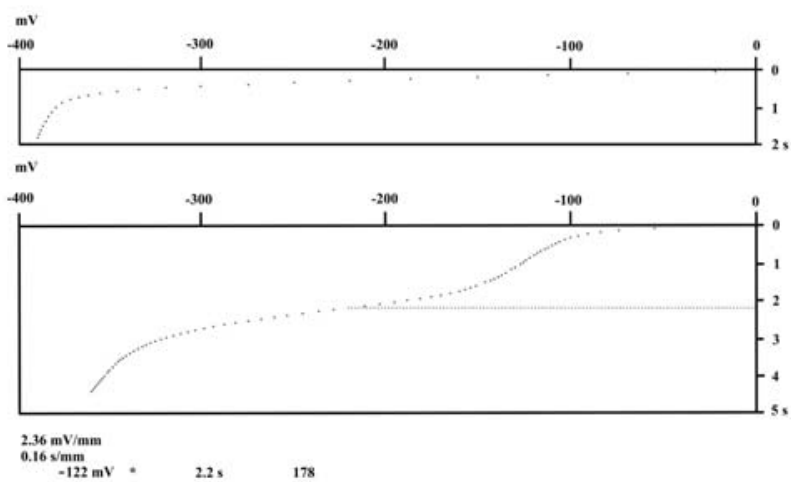

Figure 3. Chronopotentiogram at glassy carbon electrode in 0.025 $\mathrm{mol} / \mathrm{L} \mathrm{HCl}(\mathrm{a}$ - upper) in the absence and $(\mathrm{b}-$ lower) in the presence of $5 \mathrm{mg} / \mathrm{L}$ of riboflavin. $\mathrm{E}_{\text {Initial }}=0.023 \mathrm{~V}, \mathrm{I}=-1.3 \mu \mathrm{A}$.

gram obtained in solutions containing $5 \mathrm{mg} / \mathrm{L}$ of riboflavin in $0.025 \mathrm{~mol} / \mathrm{L} \mathrm{HC} 1$ is displayed in Figure $3 \mathrm{~b}$.

As can be seen, no signal was observed in the supporting electrolyte without vitamin. However, cathodic scan gave a very pronounced signal around $-0.120 \mathrm{~V}$ (vs. $\mathrm{Ag} / \mathrm{AgCl} 3.5 \mathrm{~mol} / \mathrm{L}$ ), corresponding to the two-proton twoelectron reduction of riboflavin in solution. ${ }^{18,25}$ The horizontal line shows the position of the inflection point of the chronopotentiogram corresponding to the reduction time of riboflavin (analytical signal). Experiments showed that increase in concentration of riboflavin resulted in further increasing of the reduction time. After riboflavin detection, optimisation of the analysis parameters was carried out.

\section{1. 1. Effects of the Supporting Electrolyte}

In electroanalytical studies, the choice of the supporting electrolyte is a very important step because its composition and $\mathrm{pH}$ influence the properties of the analysed solution as well as the electrode-solution interface, modifying the thermodynamics and kinetics of the charge transfer process. ${ }^{30}$ In order to choose the optimal supporting electrolyte for the chronopotentiometric determination of riboflavin, the effects of various supporting electrolytes were investigated. For this purpose, $\mathrm{HCl}, \mathrm{HNO}_{3}, \mathrm{H}_{2} \mathrm{SO}_{4}$, Na$\mathrm{Cl}, \mathrm{KCl}$, and $\mathrm{Na}_{2} \mathrm{CO}_{3}$ in concentration of $0.01 \mathrm{~mol} / \mathrm{L}$ and $0.025 \mathrm{~mol} / \mathrm{L}$ were studied. Citrate buffer $(\mathrm{pH} 4)$, acetic buffer $(\mathrm{pH} 4.7)$ and equimolar mixture solutions of $\mathrm{NaCl}$ and $\mathrm{HCl}(0.025 \mathrm{~mol} / \mathrm{L}), \mathrm{KCl}$ and $\mathrm{HCl}(0.025 \mathrm{~mol} / \mathrm{L})$ were also considered as supporting electrolytes for chronopotentiometry of riboflavin. Concentration of riboflavin was $5 \mathrm{mg} / \mathrm{L}$ in all examined supporting electrolytes. Well-defined riboflavin analytical signals were observed in all electrolytes except in $\mathrm{Na}_{2} \mathrm{CO}_{3}$. Riboflavin signal appeared in a relatively narrow potential range from -0.115 to $-0.140 \mathrm{~V}$ in $\mathrm{HCl}, \mathrm{HNO}_{3}, \mathrm{H}_{2} \mathrm{SO}_{4}$, mixture solution of $\mathrm{NaCl}$ and $\mathrm{HCl}$, and mixture solution of $\mathrm{KCl}$ and $\mathrm{HCl}$. When $\mathrm{NaCl}$ or $\mathrm{KCl}$ were used as supporting electrolytes, the reduction potential of riboflavin was shifted towards more negative values, from -0.220 to $-0.245 \mathrm{~V}$. In citric buffer signals were re- corded in potential range from -0.260 to $-0.275 \mathrm{~V}$, while in acetic buffer signals were observed between -0.310 and $-0.330 \mathrm{~V}$. Hydrochloric acid in a concentration of 0.025 mol/L was chosen as the most suitable supporting electrolyte in all subsequent electroanalytical experiments, due to the highest and sharpest riboflavin analytical signal. Beside this, reproducibility of riboflavin analytical signal was very good $(\mathrm{RSD}=2.43 \%, n=5)$, in comparison to other examined electrolytes $(\mathrm{RSD}=3.29-7.20 \%, n=5)$.

\section{1. 2. Influence of the Initial Potential}

The influence of the initial potential on riboflavin signal was investigated in the range from 0.7 to $-0.1 \mathrm{~V}$ (vs. $\mathrm{Ag} / \mathrm{AgCl}, 3.5 \mathrm{~mol} / \mathrm{L} \mathrm{KCl}$ ) in solutions containing 5 $\mathrm{mg} / \mathrm{L}$ of riboflavin in supporting electrolyte (Figure 4). The oxidation current and the ending potential were -0.8 $\mu \mathrm{A}$ and $-0.4 \mathrm{~V}$, respectively. It was observed that initial potentials higher than $0.190 \mathrm{~V}$ produced a protracted chronopotentiograms followed by a significant noise. However, at the initial potential of $-0.106 \mathrm{~V}$ the response of riboflavin was not observed. According to the height and reproducibility of riboflavin signal $(\mathrm{RSD}=2.18 \%, n=5)$, initial potential of $0.023 \mathrm{~V}$ was chosen as suitable.

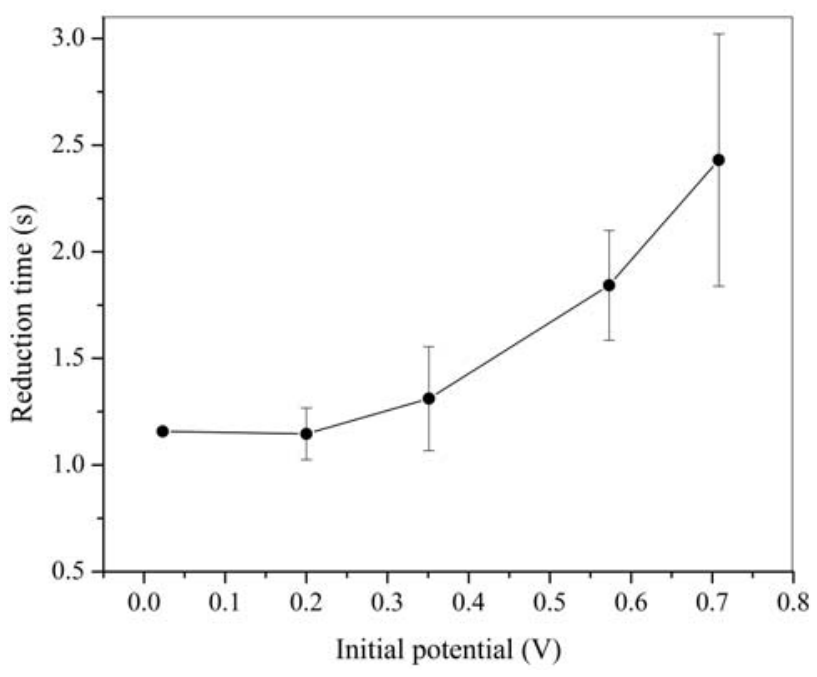

Figure 4. The influence of the initial potential on riboflavin response (mean $\pm 2 \mathrm{SD}, n=5)$. $\left(\mathrm{C}_{\text {Riboflavin }}=5 \mathrm{mg} / \mathrm{L} ; \mathrm{i}=-0.8 \mu \mathrm{A}\right)$.

\section{1. 3. Influence of the Reduction Current}

Reduction current is one of the most important experimental parameters in chronopotentiometric analysis due to its significant influence on height and sharpness of the analytical signal, i.e. the method sensitivity. Influence of the reduction current on riboflavin analytical signal in the case of planar disc electrode was investigated in model solutions containing $5 \mathrm{mg} / \mathrm{L}$ and $20 \mathrm{mg} / \mathrm{L}$ of riboflavin. Investigated ranges of the reduction current were from $-0.2 \mu \mathrm{A}$ to $-4.2 \mu \mathrm{A}$ for solutions contai- 


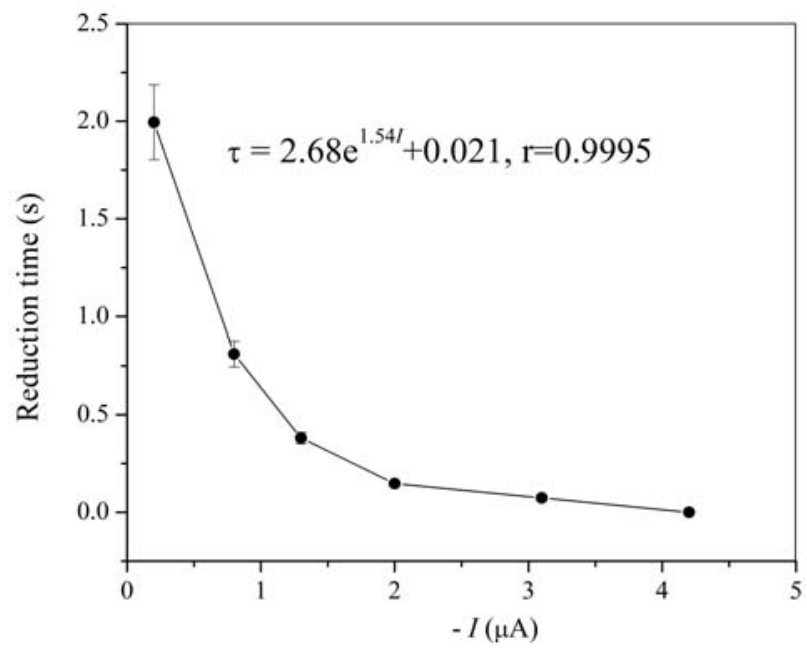

Figure 5. Influence of the reduction current on the riboflavin analytical signal (mean $\pm 2 \mathrm{SD}, n=5$ ). $\mathrm{C}_{\text {Riboflavin }}=5 \mathrm{mg} / \mathrm{L}$.

ning $5 \mathrm{mg} / \mathrm{L}$ of riboflavin and from $-2.7 \mu \mathrm{A}$ to $-6.1 \mu \mathrm{A}$ for solutions containing $20 \mathrm{mg} / \mathrm{L}$ of riboflavin. Dependence of the transition time on the reduction current defined in solutions containing $5 \mathrm{mg} / \mathrm{L}$ of riboflavin is shown in Figure 5. Each value of the reduction time is presented as a mean of five analyses, while the reproducibility for investigated current value is shown as interval around each value (2 SD).

Riboflavin reduction time exponentially decreased with increasing of the absolute current value, for both lower $\left(\tau=2.68 \mathrm{e}^{1.54 I}+0.021, r=0.9995\right)$ and higher $(\tau=$ $\left.3.78 \mathrm{e}^{0.74 I}+0.050, r=0.9996\right)$ concentrations of riboflavin. The reproducibility of the analytical signal was in the range $1.3-4.8 \%$, expressed as relative standard deviation $(n=5)$. Lower oxidation currents caused large extension of the chronopotentiogram and decrease of the reproducibility, while greater oxidation currents caused the decrease in the determination sensitivity. Considering the rectilinear sequence of the dependence $I \cdot \tau^{I / 2}=f(I)$, the reduction current interval from -0.8 to $-5.3 \mu \mathrm{A}$ was appropriate. Particular value of cathodic current from the given range was chosen considering the required sensitivity. Namely, smaller oxidation currents were used for lower concentrations of the analyte. Reduction potential of riboflavin did not vary significantly with the currents applied and was appearing at a potential range from $-0.12 \mathrm{~V}$ to $-0.14 \mathrm{~V}$ $(\mathrm{RSD}=1.84 \%, n=5)$.

\section{2. Method Validation}

The proposed chronopotentiometric method was validated with the respect to linearity, limit of detection (LOD), limit of quantification (LOQ), precision, selectivity, recovery and accuracy. All the experiments were performed under the optimized chronopotentiometric conditions.

\section{2. 1. Linearity}

Due to the great importance of the linear range of the analytical signal-concentration dependence in quantification analysis, three concentration ranges of riboflavin were observed: $0.2-2 \mathrm{mg} / \mathrm{L}, 2-12 \mathrm{mg} / \mathrm{L}$ and $10-70 \mathrm{mg} / \mathrm{L}$. Applied reduction currents were $-0.3,-2.4$ and $-5.3 \mu \mathrm{A}$, respectively. The experiments were conducted in five replicates for each concentration range. The parameters of the reduction time-concentration dependence were calculated by the least-squares method. Figure 6 presents the chronopotentiograms of various concentrations of riboflavin in $0.025 \mathrm{~mol} / \mathrm{L} \mathrm{HCl}$.

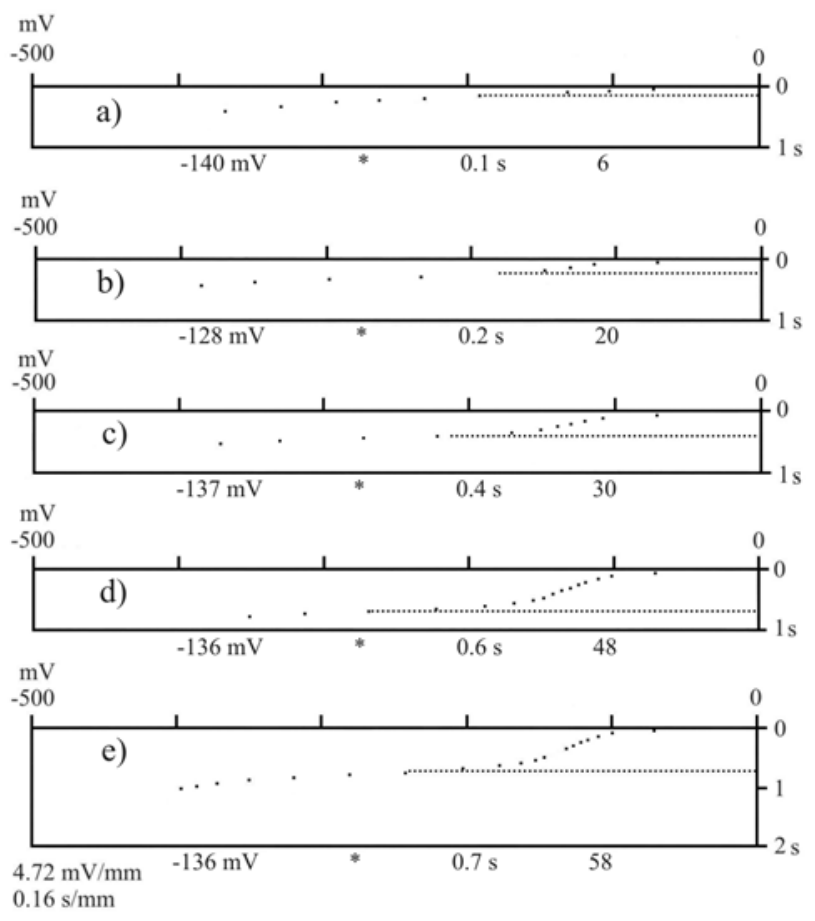

Figure 6. Chronopotentiogram of different concentration of riboflavin: (a) 10, (b) 30, (c) 40, (d) 60, and (e) $70 \mathrm{mg} / \mathrm{dm}^{3}$ in 0.025 $\mathrm{mol} / \mathrm{L} \mathrm{HCl}$. $\mathrm{E}_{\text {Initial }}=0.023 \mathrm{~V}, \mathrm{i}=-5.3 \mu \mathrm{A}$.

Under the optimal experimental conditions very good linear correlations were obtained between the measured reduction time and riboflavin concentration, for all three examined concentration ranges. Table 1 summarizes

Table 1. Linear ranges for chronopotentiometric determination of riboflavin

\begin{tabular}{lcccc}
\hline $\begin{array}{l}\text { Concentration } \\
\text { range }(\mathbf{m g} / \mathrm{L})\end{array}$ & Dependence $^{\mathrm{a}}$ & $\boldsymbol{S}_{\boldsymbol{b}}{ }^{\mathrm{b}}$ & $\boldsymbol{S}_{\boldsymbol{a}}{ }^{\mathrm{c}}$ & $\boldsymbol{r}^{\mathrm{d}}$ \\
\hline $0.2-2$ & $\tau=0.391 \times \mathrm{C}+0.208$ & 0.016 & 0.009 & 0.9966 \\
$2-12$ & $\tau=0.085 \times \mathrm{C}+0.309$ & 0.005 & 0.014 & 0.9972 \\
$10-70$ & $\tau=0.010 \times \mathrm{C}-0.054$ & 0.0002 & 0.006 & 0.9982 \\
\hline
\end{tabular}

\footnotetext{
${ }^{\text {a }} \tau$ is reduction time in s, and $C$ is concentration of riboflavin in $\mathrm{mg} / \mathrm{L} ;{ }^{\mathrm{b}} S b$, standard deviation of the slope $(n=5)$ in $\mathrm{s} \cdot \mathrm{L} / \mathrm{mg} ;{ }^{\mathrm{c}} S a$, standard deviation of the intercept $(n=5)$ in $\mathrm{s} ;{ }^{\mathrm{d}} r$, correlation coefficient of the least-squares analysis.
} 
the parameters of regression lines, standard deviations of slopes $(S b)$ and intercepts $(S a)$, as well as correlation coefficients $(r)$ of the defined linear dependences.

\section{2. 2. Limit of Detection and Limit of Quantitation}

Limit of detection (LOD) and limit of quantitation (LOQ) were calculated on the basis of $\left(3.3 \cdot S_{d} / b\right)$ and $(10$ - $\left.S_{d} / b\right)$ criteria, respectively. ${ }^{31} S_{a}$ represents the standard deviation of the intercept while $b$ represents the slope of calibration curve defined for LOD concentration range $(0.2-2 \mathrm{mg} / \mathrm{L})$. Calculated limit of detection and limit of quantitation were $0.076 \mathrm{mg} / \mathrm{L}$ and $0.23 \mathrm{mg} / \mathrm{L}$ of riboflavin, respectively. The experimental value of the detection limit was in good agreement with the calculated one and it was sufficient for simple, fast and accurate riboflavin determination in pharmaceutical preparations.

\section{2. 3. Precision}

The instrumental precision was investigated by seven consecutive analyses of blank sample containing 5 and $20 \mathrm{mg} / \mathrm{L}$ of riboflavin and the \%RSD values of the analytical signal were used to estimate it. For the evaluation of method precision (repeatability and intermediate precision), seven independent blank sample solutions containing 5 and $20 \mathrm{mg} / \mathrm{L}$ of riboflavin were prepared and analysed every day in seven consecutive days. The intraday \%RSD values of the assays results in the first day were used to examine the repeatability of the method, while the inter-day \%RSD values of seven average assay results were used to evaluate the intermediate precision. Oxidation currents applied were $-0.9 \mu \mathrm{A}$ and $-2.7 \mu \mathrm{A}$ for the lower and the higher concentration of the vitamin, respectively. In all experiments conducted in order to evaluate instrumental and method precision, \%RSD values were less than $3.84 \%$, indicating quite good precision of the proposed method for determination of riboflavin.

\section{2. 4. Interference Study}

In order to evaluate the interferences of foreign species on the chronopotentiometric determination of riboflavin, a systematic study was carried out. Problem with interference in the case of multivitamin products may come especially from other vitamins, which are the major components of multivitamin pharmaceutical preparations. Riboflavin containing pharmaceutical products, in addition to riboflavin usually contain concominants such as vitamin A, $D_{3}, E, B_{1}, B_{3}, B_{6}, B_{12}, C$, nicotinamide, folic acid and additives. The selectivity of the proposed method was evaluated by additions $1,2,5,10$ and $100 \mathrm{mg} / \mathrm{L}$ of possible interfering substances to solutions containing $1 \mathrm{mg} / \mathrm{L}$ and 5 $\mathrm{mg} / \mathrm{L}$ of riboflavin. Subsequently, the reduction times were compared with that obtained with an interferent-free riboflavin solution ( 1 and $5 \mathrm{mg} / \mathrm{L}$ ). Likewise, the additions of excipients (sucrose, lactose, glucose) were examined, but in the following concentrations: 5, 10, 20, 25 and $50 \mathrm{~g} / \mathrm{L}$.

Results of interference study are shown in Table 2.

The values in Table 2 represent the percentages of the change of riboflavin analytical signal in the presence of interfering agent. Based on the determined precision of the method (\%RSD < 3.84), the particular agent was considered to be a serious interferent when it produced the signal change of riboflavin more than $5 \%$. According to results shown in Table 2, it is obvious that the reduction time of riboflavin was not significantly affected by substantial 100 -fold excess of other tested vitamins. However, in the presence of sugars in concentrations higher than $25 \mathrm{~g} / \mathrm{L}$, no analytical signal of riboflavin was observed in solution containing $1 \mathrm{mg} / \mathrm{L}$ of riboflavin. In solutions containing $5 \mathrm{mg} / \mathrm{L}$ of riboflavin, presence of sucrose, glucose and galactose even in

Table 2. Influence of potential interfering substances on the riboflavin analytical signal

\begin{tabular}{|c|c|c|c|}
\hline \multirow[t]{2}{*}{ Interfering agent } & \multirow{2}{*}{$\begin{array}{c}\text { Concentration of } \\
\text { interference }(\mathrm{mg} / \mathrm{L})\end{array}$} & \multicolumn{2}{|c|}{ Signal change $(\%)$} \\
\hline & & $\mathrm{C}_{\text {Riboflavin }}=1 \mathrm{mg} / \mathrm{L}$ & $\mathrm{C}_{\text {Riboflavin }}=5 \mathrm{mg} / \mathrm{L}$ \\
\hline & 1 & $0.3^{\mathrm{a}}$ & 0.6 \\
\hline $\mathrm{B}_{1}, \mathrm{~B}_{3}, \mathrm{~B}_{6}, \mathrm{~B}_{12}, \mathrm{C}$ & 2 & 1.2 & 1.6 \\
\hline nicotinamide, folic & 5 & 1.3 & 1.9 \\
\hline \multirow[t]{5}{*}{ acid } & 10 & 1.4 & 1.7 \\
\hline & 100 & 2.8 & 2.2 \\
\hline & $\begin{array}{l}\text { Concentration of } \\
\text { interference }(\mathrm{g} / \mathrm{L})\end{array}$ & & \\
\hline & 5 & -1.6 & 1.4 \\
\hline & 10 & -2.7 & 1.2 \\
\hline \multirow[t]{3}{*}{ Sucrose, Glucose, Lactose } & 20 & -4.6 & -1.8 \\
\hline & 25 & 100 & -1.6 \\
\hline & 50 & 100 & -2.8 \\
\hline
\end{tabular}

${ }^{a}$ Values shown in table are maximal obtained signal change. 
10000-fold excess did not go over the value of riboflavin signal change of $5 \%$. It can be concluded that concentrations of sugars higher than $25 \mathrm{~g} / \mathrm{L}$ affect sensitivity of the method. Namely, lower concentration of riboflavin $(<5 \mathrm{mg} / \mathrm{L})$ cannot be detected when sucrose, glucose or lactose are present in concentrations higher than $20 \mathrm{~g} / \mathrm{L}$. In spite of this fact, the proposed method provided the sufficient selectivity for riboflavin determination in pharmaceutical preparations. Some other possible interference such as retinol (vitamin A), cholecalciferol (vitamin $\mathrm{D}_{3}$ ) and tocopherol (vitamin E) would not affect the determination due to their insolubility in aqueous solutions.

\section{2. 5. Accuracy}

Estimation of proposed method accuracy was done by means of HPLC parallel analyses and by calculating the recoveries in some of the pharmaceutical product samples. Obtained results are given in next section.

\section{3. Determination of Riboflavin in Pharmaceutical Preparations}

In order to verify the practical applicability of the proposed analytical method, pharmaceutical products were analysed under the optimum experimental conditions. The samples were prepared as reported in the experimental section and analysed by using the multiple standard additions method (by analysing the sample as prepared and after two standard additions). The average results for five replicate measurements with acceptable standard deviations obtained by chronopotentiometry and HPLC method are summarized in Table 3.

The determined values of riboflavin in pharmaceutical preparations are in good agreement with a content declared by manufacturer as well as with results obtained by HPLC as independent method. Namely, the paired $t$-test ${ }^{32}$ under $95 \%$ confidence level confirmed no statistically significant differences were observed between the values found by proposed chronopotentiometric and HPLC met-

Table 3. Riboflavin contents in pharmaceuticals obtained using proposed chronopotentiometric method and HPLC as reference method

\begin{tabular}{|c|c|c|c|}
\hline \multirow[b]{2}{*}{ Sample } & \multicolumn{3}{|c|}{ Riboflavin content $^{\mathrm{a}}$ (mg/tablet) } \\
\hline & $\begin{array}{c}\text { Proposed } \\
\text { chronopotentiometric } \\
\text { method }\end{array}$ & HPLC $^{\mathrm{b}}$ & $\begin{array}{c}\text { Declared } \\
\text { by } \\
\text { manufacturer }\end{array}$ \\
\hline$\overline{\text { MVT1 }}$ & $5.02 \pm 0.12$ & $4.98 \pm 0.08$ & 5.00 \\
\hline MVT2 & $3.48 \pm 0.03$ & $3.46 \pm 0.15$ & 3.40 \\
\hline BCT1 & $3.45 \pm 0.02$ & $3.42 \pm 0.04$ & 3.40 \\
\hline $\mathrm{BCT} 2$ & $4.95 \pm 0.18$ & $5.08 \pm 0.26$ & 5.00 \\
\hline \multirow[t]{2}{*}{ BCT3 } & $1.57 \pm 0.06$ & $1.62 \pm 0.05$ & 1.60 \\
\hline & \multicolumn{3}{|c|}{ Riboflavin content $^{\mathrm{a}}(\mathrm{mg} / \mathbf{1 0 0 g})$} \\
\hline$\overline{\text { MVG1 }}$ & $3.68 \pm 0.15$ & $3.74 \pm 0.18$ & 3.70 \\
\hline MVG2 & $5.11 \pm 0.14$ & $5.09 \pm 0.22$ & 5.00 \\
\hline MVG3 & $3.72 \pm 0.09$ & $3.66 \pm 0.24$ & 3.70 \\
\hline
\end{tabular}

${ }^{\mathrm{a}}$ mean $\pm \mathrm{SD}, n=5 ;{ }^{\mathrm{b}}$ Reference method.

Abbreviations: $M V T$-- multivitamin tablets, BCT - B complex tablets, $M V G$ - multivitamin granules.

Table 4. Recovery analysis of riboflavin in pharmaceuticals using proposed chronopotentiometric method $(n=5)$

\begin{tabular}{|c|c|c|c|c|c|}
\hline $\begin{array}{l}\text { Pharmaceutical } \\
\text { product }\end{array}$ & Determined & $\begin{array}{c}\text { Added } \\
\text { (mg/tablet) }\end{array}$ & Expected & Found $^{\mathrm{a}}$ & $\begin{array}{c}\text { Recovery }^{\mathrm{b}} \\
(\%)\end{array}$ \\
\hline \multirow[t]{3}{*}{ MVT1 } & 5.02 & 0.5 & 5.52 & $5.51 \pm 0.08$ & 98 \\
\hline & & 2.0 & 7.02 & $7.08 \pm 0.16$ & 103 \\
\hline & & 5.0 & 10.02 & $10.15 \pm 0.26$ & 102.6 \\
\hline \multirow[t]{4}{*}{ BCT1 } & 3.45 & 0.5 & 3.95 & $3.92 \pm 0.09$ & 94 \\
\hline & & 2.0 & 5.45 & $5.52 \pm 0.18$ & 103.5 \\
\hline & & 5.0 & 8.45 & $8.36 \pm 0.12$ & 98.2 \\
\hline & & (mg/100g) & & & $(\%)$ \\
\hline \multirow[t]{3}{*}{$\overline{\mathrm{MVG} 1}$} & 3.68 & 0.5 & 4.18 & $4.16 \pm 0.14$ & 96 \\
\hline & & 2.0 & 5.68 & $5.64 \pm 0.26$ & 98 \\
\hline & & 5.0 & 8.68 & $8.82 \pm 0.22$ & 102.8 \\
\hline
\end{tabular}

\footnotetext{
${ }^{\mathrm{a}}$ mean $\pm \mathrm{SD}, n=5 ;{ }^{\mathrm{b}}$ Mean Recovery $(\%)=($ Found-Determined $) /$ Added $\cdot 100, n=5$.
} 
Table 5. Comparison of the proposed method with some previously reported electrochemical methods for determination of riboflavin

\begin{tabular}{|c|c|c|c|c|c|}
\hline Method & Electrode & Supporting electrolyte & Linear range $(\mathrm{mg} / \mathrm{L})$ & LOD (mg/L) & Reference \\
\hline$\overline{\text { SWASV }}$ & Cyclam modified CPE & Britton-Robinson buffer, pH 1.5 & $0.5 \cdot 10^{-3}-70$ & $0.2 \cdot 10^{-3}$ & 2 \\
\hline SWASV & DNA-CNT & $0.1 \mathrm{~mol} / \mathrm{L} \mathrm{H}_{3} \mathrm{PO}_{4}$ & $\begin{array}{c}1 \cdot 10^{-6}-10 \cdot 10^{-6} \\
10 \cdot 10^{-6}-170 \cdot 10^{-6} \\
5 \cdot 10^{-3}-105 \cdot 10^{-3}\end{array}$ & $0.2 \cdot 10^{-6}$ & 22 \\
\hline $\mathrm{CV}$ & $\mathrm{Co}^{2+}-\mathrm{Y}$ zeolite modified CPE & $0.1 \mathrm{~mol} / \mathrm{L} \mathrm{KNO}_{3}, \mathrm{pH} 5.0$ & $0.65-12.80$ & 0.27 & 24 \\
\hline AdSWV & Sparked-BiSPEs & Acetate buffer, $\mathrm{pH} 4.5$ & $0.38 \cdot 10^{-3}-37.63 \cdot 10^{-3}$ & $0.26 \cdot 10^{-3}$ & 28 \\
\hline AdSWV & $\mathrm{BiFE}$ & Acetate buffer, $\mathrm{pH} 4.0$ & $\begin{array}{l}0.11-0.30 \\
0.38-3.39\end{array}$ & 0.0378 & \\
\hline $\begin{array}{l}\text { Chronopoten- } \\
\text { tiometry }\end{array}$ & GCE & $0.025 \mathrm{~mol} / \mathrm{L} \mathrm{HCl}$ & $\begin{array}{c}0.2-2 \\
2-12 \\
10-70\end{array}$ & 0.076 & This work \\
\hline
\end{tabular}

Abbreviations: SWASV- Square-wave anodic striping voltammetry; DNA-CNT - DNA immobilised carbon nanotube mixed paste electrode; AdSWV - Adsorptive square-wave voltammetry; BiSPE - Bismut graphite screen-printed electrode; BiFE - Bismuth film electrode; CPE - Carbon paste electrode; GCE - Glassy carbon electrode.

hods $\left(|\mathrm{t}|=0.38<\mathrm{t}_{7,0.05}=2.36\right)$, as well as between the values declared by manufacturer and values determined by chronopotentiometry $\left(|\mathrm{t}|=1.15<\mathrm{t}_{7,0.05}=2.36\right)$. Accuracy of the method was accompanied with very high reproducibility of the results $(\mathrm{RSD}=4.08 \%, n=5)$.

The validity of method was additionally checked by recovery determinations of riboflavin with triple spiking of the pharmaceutical product samples MVT1, BCT1 and MVG1. The results are summarized in Table 4.

The recovery values ranged from 94 to $103.5 \%$. These values of recovery indicated that there are no significant matrix interferences in the analysed samples as well as that the presented method is sufficiently accurate and suitable for riboflavin determination in pharmaceutical products.

\section{4. Comparison With Other Electrochemical Methods}

A comparison of the analytical performance of our proposed method with some other reported electrochemical methods for riboflavin determination are given in Table 5 . As it was mentioned earlier, no established electrochemical method for riboflavin determination by using chronopotentiometry has been published to date in literature. Concerning the sensitivity of riboflavin determination, it is evident that various types of modified electrodes ${ }^{2,22,28}$ provide the lowest LOD. Beside surface modification, an additional contribution to sensitivity increase is achieved by pre-concentration step (stripping techniques). The pre-concentration step could decrease the reproducibility of results and prolongs the time of analysis. Beside this, the preparation of chemically modified electrodes is complex and time consuming process that usually involves various steps in incorporation of the different, often expensive, modifiers to the electrode surface leading to the results that are not always reproducible. ${ }^{33}$ Sometimes it is unnecessary to modify electrode surface for the purpose of sensitivity improvements in a practical analysis, reducing expenses as well as manipula- tion time relating to electrode modification. In our experiments satisfactory limit of detection and good linear concentration range were obtained without any electrode pretreatment with whole analysis time round 1-5 s.

\section{Conclusions}

A glassy carbon planar disc electrode was applied as an electrochemical sensor in combination with chronopotentiometry to elaborate a sensitive, selective and cheap alternative analytical method for direct determination of riboflavin in pharmaceuticals. The optimum experimental conditions were found as follows: $0.023 \mathrm{~V}$ initial potential, $-0.4 \mathrm{~V}$ ending potential and reduction current range from $-0.8 \mu \mathrm{A}$ to $-5.3 \mu \mathrm{A}$ in an electrolyte solution of 0.025 $\mathrm{mol} / \mathrm{L} \mathrm{HCl}$. The calibration curves displayed good linearity within the observed concentration ranges $(0.2-2 \mathrm{mg} / \mathrm{L}$, 2-12 $\mathrm{mg} / \mathrm{L}$, and 10-70 mg/L). Relatively low detection limit of $0.076 \mathrm{mg} / \mathrm{L}$ of riboflavin was obtained regardless that no modification of the glassy carbon surface or electrochemical treatments were involved. When applied to pharmaceutical formulations, the developed method yielded results that were in good agreement with those obtained by HPLC method as comparative reference method. The proposed chronopotentiometric method is found to be practically rapid, convenient, accurate and precise for riboflavin determination in pharmaceutical preparations. Therefore it can be concluded that this electrochemical method represents a valuable addition in the field of analytical chemistry for the determination of vitamins.

\section{Acknowledgements}

The financial support of the Ministry of Education, Science and Technological Development of the Republic of Serbia (Project III 46009) is gratefully acknowledged. 


\section{References}

1. L. Bandžuchová, R. Šelešovská, T. Navrátil, J. Chýlková, L. Novotný, Electrochim. Acta 2012, 75, 316-324. http://dx.doi.org/10.1016/j.electacta.2012.05.009

2. R. M. Kotkar, P. B. Desai, A.K. Srivastava, Sens. Actuators, B. 2007, 124, 90-98. http://dx.doi.org/10.1016/j.snb.2006.12.004

3. H. J. Powers, Am. J. Clin. Nutr. 2003, 77, 1352-1360.

4. G. F. M. Ball, Vitamins in foods. Analysis, Bioavailability, and Stability: Taylor \& Francis Group, Boca Raton, 2006.

5. N. Reavley: The New Encyclopedia of Vitamins, Minerals, Supplements, and Herbs: A completely Cross-Referenced User's Guide for Optimal Health, M. Evans \& Company, New York, USA, 1999.

6. AOAC: Official Methods of Analysis, sixteenth ed., Association of Official Analytical Chemist, Arlington, USA, 1995.

7. J. J. Berzaas Nevado, J. Rodriguez Flores, M. J. Villaseñor Llerena, Fresenius J. Anal. Chem. 1994, 350, 610-613.

8. T. Pérez-Ruiz, C. Martínez-Lozano, V. Tomás, O. Val, Analyst 1994, 119, 1199-1203. http://dx.doi.org/10.1039/an9941901199

9. F. J. Aberásturi, A. I. Jiménez, J. J. Arias, F. Jiménez, Anal. Lett. 2002, 35, 1677-1691. http://dx.doi.org/10.1081/AL-120013047

10. A. Safavi, M. A. Karimi, M. R. Hormozi Nezhad, Luminescence 2005, 20, 170-175. http://dx.doi.org/10.1002/bio.811

11. S. Hustad, P. M. Ueland, J. Schneede, Clin. Chem. 1999, 45, 862-868.

12. A-K. Su, C-H. Lin, J.Chromatogr. B 2003, 785, 39-46. http://dx.doi.org/10.1016/S1570-0232(02)00849-8

13. A-K. Su, Y-S Chang, C-H Lin, Talanta 2004, 64, 970-974. http://dx.doi.org/10.1016/j.talanta.2004.04.011

14. É. Barna, E. Dworschák, J. Chromatogr. A 1994, 668, 359363. http://dx.doi.org/10.1016/0021-9673(94)80126-6

15. P. Moreno, V. Salvadó, J. Chromatogr. A 2000, 870, $207-$ 215. http://dx.doi.org/10.1016/S0021-9673(99)01021-3

16. R. Gatti, M. G. Gioia, Anal. Chim. Acta 2005, 538, 135-141. http://dx.doi.org/10.1016/j.aca.2005.02.025

17. P. Jin, L. Xia, Z. Li, N. Che, D. Zou, X. Hu, J. Pharm. Biomed. Anal. 2012, 70, 151-157.

http://dx.doi.org/10.1016/j.jpba.2012.06.020

18. W. Qijin, Y. Nianjun, Z. Haili, Z. Xinpin, X. Bin, Talanta 2001, 55, 459-467.
http://dx.doi.org/10.1016/S0039-9140(01)00437-4

19. A. Safavi, N. Maleki, H. Ershadifar, F. Tajabadi, Anal. Chim. Acta 2010, 674, 176-181.

http://dx.doi.org/10.1016/j.aca.2010.06.012

20. A. Economou, P. R. Fielden, Electroanalysis 1995, 7, 447453. http://dx.doi.org/10.1002/elan.1140070508

21. S-H. Wu, J-J. Sun, Z-B. Lin, A-H. Wu, Y-M. Zeng, L. Guo, D-F. Zhang, H-M. Dai, G-N. Chen, Electroanalysis 2007, 19, 2251-2257. http://dx.doi.org/10.1002/elan.200703959

22. S. Y. Ly, H.S. Yoo, J. Y. Ahn, K. H. Nam, Food. Chem. 2011, 127, 270-274.

http://dx.doi.org/10.1016/j.foodchem.2010.12.107

23. M. J. F. Villamil, A. J. Miranda Ordieres, A. Costa García, P. Tuñón Blanco, Anal. Chim. Acta 1993, 273, 377-382. http://dx.doi.org/10.1016/0003-2670(93)80180-S

24. A. Nezamzadeh-Ejhieh, P. Pouladsaz, J. Ind. Eng. Chem. 2014, 20, 2146-2152. http://dx.doi.org/10.1016/j.jiec.2013.09.044

25. K-K. Shiu, K. Shi, Electroanalysis 2000, 20, 134-139. http://dx.doi.org/10.1002/(SICI)1521-4109(200002)12:2 $<134:$ :AID-ELAN134>3.0.CO;2-V

26. I. O. Marian, N. Bonciocat, R. Săndulescu, C. Filip, J. Pharm. Biomed. Anal. 2001, 24, 1175-1179. http://dx.doi.org/10.1016/S0731-7085(00)00580-X

27. D. Riman, A. Avgeropoulos, J. Hrbac, M. I. Prodromidis, Electrochim. Acta 2015, 165, 410-415.

http://dx.doi.org/10.1016/j.electacta.2015.03.056

28. É. S. Sá, P. S. da Silva, C. L. Jost, A. Spinelli, Sens. Actuators, B 2015, 209, 423-430. http://dx.doi.org/10.1016/j.snb.2014.11.136

29. J. Švarc-Gajić, Z. Stojanović, Food. Chem. 2011, 124, 11721176. http://dx.doi.org/10.1016/j.foodchem.2010.07.030

30. L'. Švorc, M. Rievaj, D. Bustin, Sens. Actuators, B 2013 , 181, 294-300. http://dx.doi.org/10.1016/j.snb.2013.02.036

31. ICH: Guidance for Industry, Q2B Validation of Analytical Procedures: Methodology, ICH, 1996.

32. J. Miller, J. C. Miller, Statistics and Chemometrics for Analytical Chemistry, sixth ed.: Pearson Education, Harlow, UK, 2010.

33. L'. Švorc, J. Sochr, M. Rievaj, P. Tomčík, D. Bustin, Bioelectrochemisty 2012, 88, 36-41.

http://dx.doi.org/10.1016/j.bioelechem.2012.04.004

\section{Povzetek}

Razvili smo novo, preprosto, občutljivo in zanesljivo elektrokemijsko metodo za določanje riboflavina na osnovi kronopotenciometrije s steklasto ogljikovo elektrodo. Glede na analizni signal riboflavina smo optimizirali najpomembnejše inštrumentalne parametere kronopotenciometrije, kot so tip in koncentracija elektrolita, začetni potencial in tokovno območje. Riboflavin je dal dobro definiran signal za redukcijo pri -0,12 V vs. Ag/AgCl (3,5 mol/L KCl) elektrodi v 0,025 $\mathrm{mol} / \mathrm{L} \mathrm{HCl}$. Pri optimalnih pogojih smo opazili linearen odgovor za riboflavin v koncentracijskem območju 0,2-70 $\mathrm{mg} / \mathrm{L}$ z doseženo mejo zaznave $0,076 \mathrm{mg} / \mathrm{L}$ in mejo določitve $0,23 \mathrm{mg} / \mathrm{L}$ riboflavina. Običajni vitamini in polnila niso motili določitve. Predlagano metodo smo uspešno uporabili za določitev riboflavina v komercialno dostopnih farmacevtskih proizvodih. Rezultati so se statistično ujemali z vsebnostjo, ki jo je deklariral proizvajalec, in z rezultati HPLC, ki smo jo uporabili kot primerjalno metodo. 